Ewa Mrozek-Sadowska

Independent scholar

\title{
Fårö, wyspa Bergmana
}

Pamięci Egila Törnqvista (1932-2015)

Fårö, Bergman’s Island

This paper is an attempt to investigate the relationship between Ingmar Bergman, the Swedish auteur and the island of Fårö in the Baltic, where he worked and lived for 40 years. Bergman said: "If one wished to be solemn, it could be said that I had found my landscape, my real home; if one wished to be funny, one could talk about love at first sight." He discovered the island when looking for a location to shoot Through a Glass Darkly. Including Through a Glass Darkly, Bergman was to shoot six films and one television series on Fårö. He also made two documentary films about the island and its inhabitants: Fårö Document 1969 and Fårö Document 1979.

Key words: Ingmar Bergman, Fårö, island, Swedish film

Słowa klucze: Ingmar Bergman, Fårö, wyspa, film szwedzki

\section{Wstęp}

Szwedzki reżyser Ingmar Bergman (1918-2007) przybył na wyspę Fårö w 1960 roku, siedem lat później zbudował na niej dom, w którym początkowo mieszkał przez kilka miesięcy w roku, a potem zamieszkał na stałe. Na wyspie pisał swoje książki, scenariusze i kręcił filmy. Tam założył własną wytwórnię filmową. Tam też zmarł i został pochowany.

Słownik języka polskiego podaje dwa znaczenia słowa „wyspa”: dosłowne, gdy jest to „część lądu otoczona ze wszystkich stron wodą morza, jeziora lub rzeki”, oraz metaforyczne jako „miejsce wyróżniające się z otoczenia”. Do położonej na Bałtyku u wybrzeży Gotlandii maleńkiej wyspy Fårö odnoszą się oba, gdyż jej krajobraz należy do wysoce wyjątkowych, odróżniając ją od innych szwedzkich krajobrazów ${ }^{1}$. Na przestrzeni około stu kilometrów kwadratowych wyspa zaska-

\footnotetext{
${ }^{1}$ Nietypowy dla Skandynawii charakter mają także wyspy Olandia i Gotlandia, jednak krajobraz Fårö wyróżnia się także na ich tle.
} 
kuje swoją różnorodnością i zadziwia bogactwem kontrastów. Na tej niewielkiej powierzchni sąsiadują ze sobą rozległe łąki, wrzosowiska, lasy, bagna i trzęsawiska, ruchome wydmy, jeziora, plaże piaszczyste, kamienne i skaliste, oraz te najbardziej niecodzienne formy skalne - rauki.

W epoce syluru, ponad 400 milionów lat temu, Fårö należała wraz z Gotlandią do paleokontynentu Bałtyka, znajdującego się w strefie tropikalnej, położonej około $20^{\circ}$ na południe od równika (Copper 2004: 1). Wyspa jest pozostałością uformowanych wtedy raf koralowych, które wskutek ciągłego wypiętrzania się terenu znalazły się nad poziomem morza, a przybierające fantazyjne kształty wapienne ostańce powstały w wyniku erozji wapnia marglistego, mniej odpornego niż bardziej trwały wapień koralowy, z którego zbudowane są rauki (Erlström 2009: 20).

Jednak to nie one przyciągnęły Bergmana, wręcz przeciwnie, znał je przecież jak każdy Szwed ze zdjęć i pocztówek i właśnie dlatego nie chciał kręcić tam filmów - wapienne formy były według niego zbyt charakterystyczne.

\section{Odkrycie Fårö}

Reżyser trafił na Fårö w pewnym sensie wbrew własnej woli, poszukując plenerów do filmu Jak w zwierciadle (1961). Rzecz rozgrywać się miała na odizolowanej, surowej wyspie i ani sztokholmskie szkiery, na których powstały Wakacje $z$ Monika (1952), ani kamienne wybrzeże Skanii, gdzie nakręcono Wieczór kuglarzy (1953) i Siódma pieczęć (1956), nie odpowiadały wizji reżysera, która zgodnie ze zwyczajem twórcy była nader dokładna:

W 1960 roku miałem zrobić film zatytułowany Jak $w$ zwierciadle o czworgu ludzi na wyspie. W pierwszej scenie wynurzają się oni ze wzburzonego morza. Chciałem, nie będąc tam przedtem, żeby nagranie odbyło się na Orkadach. Kierownictwo produkcji załamywało ręce wobec kosztów i oddało mi do dyspozycji helikopter, żebym szybko mógł przeszukać szwedzkie wybrzeże. Obejrzałem je i wróciłem jeszcze bardziej zdecydowany kręcić na Orkadach. Niemal zdesperowana administracja wspomniała o Fårö. Fårö miała być podobna do Orkadów. Ale tańsza. Bardziej praktyczna. Dostępniejsza. Aby położyć kres wszelkim dyskusjom, udaliśmy się w pewien burzliwy kwietniowy dzień na Gotlandię, by pospiesznie obejrzeć Fårö i potem definitywnie zdecydować się na Orkady. Rozklekotana taksówka czekała w Visby i zawiozła nas przez deszcz i śnieg do przystani promowej. Po przeprawie przy silnie wzburzonym morzu wylądowaliśmy na Fårö. A potem ze szczękiem i zgrzytem pojechaliśmy po śliskich i krętych drogach dookoła wyspy wzdłuż brzegu.

W filmie jest wyrzucony na brzeg wrak. Skręciliśmy za skalisty cypel, a tam leżał wrak, rosyjski kuter do połowu łososia, dokładnie taki, jaki opisałem. Stary dom miał stać w małym ogrodzie ze starymi jabłoniami. Znaleźliśmy ogród, dom mogliśmy zbudować. Miało tam być kamieniste wybrzeże i znaleźliśmy je, zwrócone ku wieczności (Bergman 1991: 197). 
Powyższy opis jest tylko jedną z wersji wielokrotnie przytaczanej, legendarnej już opowieści o odkryciu przez Bergmana wyspy ${ }^{2}$. Sam reżyser z typową dla siebie lekkością do tworzenia barwnych narracji prezentował różne wariacje na jej temat ${ }^{3}$. Aż trzy znaleźć możemy w jednej tylko publikacji Fårö och Ingmar Bergman. Ett möte (2014), zamieszczono w niej bowiem rozmowę Bergmana $\mathrm{z}$ Ainą Larsson z 1972 roku, fragmenty jego autobiograficznej książki Laterna magica z 1987 oraz wywiad przeprowadzony w 2003 roku przez Tobiasa Fröberga. Jak podkreślają autorki antologii, już we wstępie Bergman dopasowuje swoje wspomnienia do sytuacji i osób, którym je przekazuje, we wszystkich wersjach obecne jest jednak poczucie, że oto odnalazł on swoje miejsce na ziemi.

W Laterna magica reżyser pisze: „Właściwie nie wiem, co się stało. Mówiąc uroczyście, znalazłem swój krajobraz, swój rzeczywisty dom. Jeśli chce się być dowcipnym, można mówić o miłości od pierwszego wejrzenia" (Bergman 1991: 198). Podobnie widział to Nykvist, odnotowując: „Ingmar zakochał się bez pamięci. Jałowy krajobraz między morzem a niebem stał się jego domem” (Nykvist 2006: 82).

\section{Dlaczego Fårö?}

W swoich wspomnieniach Bergman wyjaśniał, że jego przywiązanie do Fårö miało wiele powodów. Intuicja podpowiadała mu, że to jego krajobraz i że odpowiadał on jego „najgłębszym wyobrażeniom o kształtach, proporcjach, kolorach, horyzontach, dźwiękach, ciszach, światłach i refleksach”. Na wyspie czuł się bezpiecznie. Krajobraz Fårö dawał mu „uproszczenie, proporcje, napięcie, odprężenie i oddech", których poszukiwał w swoim zawodzie. Znajdował tam też przeciwwage dla pracy w teatrze. „Na morskim brzegu - przyznawał - mogę szaleć i ryczeć. No, najwyżej wzbije się w powietrze jakaś mewa. Na scenie byłaby to katastrofa" (Bergman 1991: 198).

\footnotetext{
${ }^{2}$ Największe rozbieżności dotyczą tego, kto doradził Bergmanowi odwiedzenie Fårö. Według badaczki Birgitty Steene osobą tą był jego operator Sven Nykvist (Steene 2005: 40). Nykvist twierdzi z kolei, że to ktoś inny polecił reżyserowi tę lokalizację, nie mówi jednak, kto (Nykvist 2006: 82). W biografii Timma jest to technik współpracujący przy filmie (Timm 2008: 321).

${ }^{3}$ Przytoczona tu wersja $\mathrm{z}$ autobiografii Laterna magica przywodzi na myśl powieść Augusta Strindberga Mieszkańcy Hemsö rozpoczynającą się słynnym zdaniem: „Pewnego kwietniowego wieczoru pojawił się niczym zawierucha” (Strindberg 1895: 5) („Han kom som ett yrväder en aprilafton” Strindberg 1914: 7). Główny bohater tej popularnej w Szwecji, a nieznanej w Polsce powieści, parobek Carlsson, przybywa na wyspę Hemsö, aby ratować gospodarstwo wdowy, po czym obejmuje je w posiadanie. Wydaje się, że nawiązanie do dzieła Strindberga nie jest przypadkowe. Bergman doskonale znał twórczość wielkiego Szweda i bardzo ją cenił, a sam Strindberg był dla niego wzorem.
} 
Na pytanie, skąd zauroczenie i fascynacja wyspą, Bergman odpowiadał wielokrotnie. I tak jak w opowieści o odkryciu Fårö wersji odpowiedzi było wiele. W wywiadzie przeprowadzonym przez Lasse Bergströma w 1991 roku pod wymownym tytułem Stary człowiek i morze (Bergström 1991) reżyser skupił się głównie na naturze tego wyjątkowego miejsca. Podkreślał, że pociąga go nieustający szum wiatru, fal, odgłosy mew. Podobnie jak we wspomnieniach duże znaczenie przypisywał poczuciu bezpieczeństwa, jakie według niego dawał ogrom morza. Dzięki niemu miał wrażenie bycia poza zmianami i czasem. Istotne były proporcje i pradawny charakter krajobrazu. Mówil, że choć na wyspie nie ma „mnóstwa listowia, piaszczystych plaż, klifów i skał ani lasów, to każdy z tych elementów występuje w cudownej równowadze i harmonii”. Wymieniał niskie kamienne murki przecinające płaski krajobraz, „który wydawać się może surowy i ponury, ale po wiosennych roztopach zamienia się w olbrzymi dywan koloru i życia”. I wreszcie światło - przyznawał, że godzinami może obserwować jego grę przez okno (Bergström 1991: 43-45).

Kilka lat później w rozmowie z Johnem Lahrem Bergman wyjaśnia, że powodem, dla którego mieszka na Fårö, jest poczucie całkowitej równowagi, jakie tam odczuwa. Równowagę zapewniają: morze, dom, samotność, światło. „Wszystko jest bardziej przejrzyste. Dużo bardziej precyzyjne"4. Innym razem wyznaje, że kiedy jest w Sztokholmie, codziennie tęskni za wyspą, za morzem i naturą (Lahr 1999). Mawiał zresztą, że w Sztokholmie tylko mieszka, a na Fårö żyje (Timm 2008: 571).

\section{Dom na Fårö}

Po zakończeniu prac nad Personą, drugim filmem nakręconym na Fårö, Bergman kupił tam ziemię i postanowił wybudować dom. W mowie skierowanej do robotników z okazji zawieszenia wiechy na domu w Hammars w 1967 roku pisze:

Od dawna marzyłem o domu nad morzem, o pracowni zwróconej na morski horyzont, o odosobnieniu i o bliskości do natury. Długo myślałem, że pozostanie to tylko niespełnionym marzeniem. Wzdłuż wielu wybrzeży w Szwecji i za granicą na próżno szukałem odpowiedniego miejsca. Tutaj spełniają się moje marzenia (cyt. za: Warnecke i Jaspers (red.) 2011: 69).

Niewiele brakowało, a marzenie pozostałoby niespełnione, ponieważ pojawiły się trudności w uzyskaniu pozwolenia na budowę tak blisko plaży. Ale gmina Fårö poparła projekt, słusznie przewidując wiążące się z nim korzyści dla regionu.

Zdaniem wybitnego duńskiego architekta Steena E. Rasmussena „architekt jest jakby producentem teatralnym, człowiekiem aranżującym scenę, na której

${ }^{4} \mathrm{O}$ ile nie podano inaczej, wszystkie cytaty w moim tłumaczeniu (E.M-S.). 
toczy się nasze życie" (Rasmussen 2015: 12). Podobnego zdania był Kjell Abramson, architekt, który otrzymał zlecenie zaprojektowania domu. Poprosił on swojego zleceniodawcę o listę życzeń, porównując wspólne planowanie domu do współpracy reżysera i scenografa (Timm 2008: 397). Punktem wyjścia dla projektu domu były dwa meble: zegar dziadka i szafa babci. Wokół nich, a dokładniej rzecz biorąc, wzdłuż nich powstała przedziwna budowla ${ }^{5}$, na planie rozciągniętego prostokąta, rozbudowywana przez lata przez innego już architekta, Pera Erika Nilssona ${ }^{6}$.

Położony na kamiennej plaży w Hammars prosty, parterowy drewniany budynek, otoczony od strony lądu murem i sosnowym lasem, wtapia się w krajobraz. Wnętrze też jest proste, funkcjonalne, wyłożone drewnianą boazerią, wyraźnie dostosowane do potrzeb jednej osoby ${ }^{7}$.

Obok wspomnianych już odziedziczonych zegara i szafy rozpoznać w nim można klasyki designu: fotel z podnóżkiem Charlesa Eamesa, biurko Carla Malmstena i fotel Bruno Mathssona. Centralne miejsce w salonie zajmuje zaprojektowany przez Bergmana piec z miejscem do leżenia, którego inspiracją było kino rosyjskie ${ }^{8}$.

Oprócz domu w Hammars reżyser posiadał jeszcze inne nieruchomości na wyspie. W bezpośrednim sąsiedztwie domu znajdowała się „chatka do pisania” (skrivarstuga), a także dom Ängen, wzniesiony w latach 80. z myślą o gościach. W położonej kilka kilometrów dalej osadzie Dämba Bergman kupił całe gospodarstwo wraz z zabudowaniami: domem mieszkalnym, stodołami i wiatrakiem. W sumie jego posiadłość na Fårö rozrosła się do 34 hektarów.

\section{4. „Chata artysty” na Fårö}

Niemiecki filozof Martin Heidegger przez niemal pół wieku pisał swoje dzieła w prostej, maleńkiej chatce $\mathrm{z}$ widokiem na dolinę w szwarcwaldzkich lasach. Swojemu schronieniu, nazywanemu Heidegger's Hütte, poświęcił esej, podkreślając intelektualną i emocjonalną bliskość z budynkiem i jego otoczeniem. Architekt Adam Sharr zanalizował skomplikowaną relację między myślą, miejscem a osobą filozofa, proponując różne sposoby oglądu słynnej Hütte: od terenu konfrontacji między człowiekiem a jego egzystencją, poprzez drobnomieszczańską

\footnotetext{
${ }^{5}$ O domu w Hammars opowiadają filmy dokumentalne: Bergman i wyspa Fårö (2003) w reż. Marie Nyreröd i Więcej niż Bergman (2013) w reż. Jane Magnusson i Hynka Pallasa.

${ }^{6}$ Więcej na temat współpracy Bergmana z Nilssonem zob. Edlund 2014: 151-162. W ostatecznej wersji dom osiągnął długość 56 metrów.

7 A przecież, jak pisał sam pomysłodawca, zbudował go z myślą o wspólnym życiu na wyspie z Liv Ullmann i ich córeczką Linn (Bergman 1991: 198).

${ }^{8}$ Mówi o tym w dokumencie Bergman i wyspa Fårö (2003).
} 
ucieczkę zagubionego romantyka, po zwyczajny i niewyróżniający się niczym niewielki budynek.

Oprócz chatki Heideggera znane są przykłady innych samotni służących jako skromne i odizolowane miejsce pracy twórcom różnych epok, takie jak: wieża Hölderlina w Tübingen, malowniczy Gartenhaus Goethego w Weimarze, górski domek Nietzschego w Sils Maria w szwajcarskich Alpach, chatka Thoreau nad stawem Walden, chata Wittgensteina w norweskim Skjølden czy wieża Junga w Bollingen (Sharr 2006: 75). Owe refugia twórców przynależą do liczącej trzy tysiące lat dalekowschodniej tradycji traktowania chaty jako miejsca do uprawiania poezji i filozofii (Weston 2011: 79). Dom Bergmana na Fårö, w którym napisał większość scenariuszy i książek, doskonale wpisuje się w tę tradycję.

\section{Twierdza Fårö}

Twórcze odosobnienie, ucieczka $\mathrm{z}$ miasta i powrót do natury przybierały na Fårö formę totalną. Należy pamiętać, że część terytorium wyspy do 1998 roku była terenem wojskowym, do którego obcokrajowcy nie mieli dostępu. Aby dostać się na wyspę, potrzebne było specjalne zaproszenie ${ }^{9}$. „Pustelnik z Fårö - jak Tadeusz Szczepański określił Bergmana w swojej monografii - rygorystycznie strzegący sekretów swojej ekskluzywnej prywatności” (Szczepański 1999: 391) wybrał miejsce idealne, w którym mógł realizować ideę odizolowania na własnych warunkach.

Życie na wyspie ułatwiało mu panowanie nad wieloma aspektami egzystencji, co było konieczne przy wprost chorobliwej potrzebie kontroli. Bergman zdawał sobie z tego sprawę, kiedy pisał: „Myśl, [...] że istniało coś, nad czym nie mogłem panować, czego nie mogłem przewidzieć, była dla mnie źródłem ustawicznego przerażenia” (Bergman 1993: 240). Utraty kontroli bał się bardziej niż śmierci. Ograniczone terytorium wyspy dawało możliwość kontrolowania terenu, więc by ułatwić tę kontrolę, reżyser postawił mur ${ }^{10}$ dookoła domu, żeby - jak wspominała Ullmann - nikt nie mógł ich odwiedzać (Bjørnstad 2007: 60).

„Samorzutnie wybrana samotność jest znośna. Oszańcowałem się [...]” - pisał Bergman (Bergman 1991: 198), a w dzienniku roboczym 30 września 1968 roku odnotował: „Na własne życzenie jestem całkowicie odizolowany; jest to dość przyjemne" (Bergman 1993: 298). Twierdził też, że dążenie do minimalizacji i uproszczenia

\footnotetext{
9 Procedurę dostania się na wyspę barwnie opisała Rita Russek, niemiecka aktorka i współpracowniczka Bergmana, w niepublikowanym wywiadzie z Angeliką Mrozek-Abraham podczas sesji Das Theater als Ehefrau, der Film als Geliebte w Evangelische Akademie w Tutzing 2-4.02.2018.

${ }^{10}$ W filmie Więcej niż Bergman szwedzki reżyser Tomas Alfredson porównuje kamienny mur z drutem kolczastym wokół domu w Hammars do muru berlińskiego.
} 
zawsze było jego podnietą (Bergman 1993: 68). Stąd nie dziwi, że gdy po opuszczeniu Teatru Dramaten do wyboru miał cały świat i mógł robić, co chciał, „całym światem" okazała się wyspa Fårö (Gado 1986: 315). Bergman - jak ujął to jego zięć, pisarz Henning Mankell - „niczym bohater Burzy Szekspira, samotny Prospero” osiadł na swojej wyspie (Mankell 2011: 98) ${ }^{11}$.

Fårörska samotność Bergmana przywodzi na myśl traktat pedagogiczny Jeana-Jacques’a Rousseau Emil, czyli o wychowaniu, który w ujęciu Andrzeja Waśkiewicza ,jest modelem życia w szczególnym miejscu w społeczeństwie, a dokładnie na jego uprzywilejowanym marginesie" (Waśkiewicz 2007: 63). Podobnie jak Emil twórca Persony żył nie poza wspólnotą, ale obok niej; był obcy, ale nie wyobcowany; sam, ale nie samotny, bo samotności nie odczuwał ${ }^{12}$.

\section{Filmy na Fårö}

Wyspa to stały topos w filmach Bergmana. Surowe wyspiarskie scenerie fascynowały go już na wczesnym etapie twórczości ${ }^{13}$. To w ich poszukiwaniu odkrył tę maleńką wysepkę u brzegów Gotlandii, która miała zmienić jego życie i wejść do historii filmu.

$\mathrm{Na}$ Fårö powstały w sumie cztery filmy fabularne: Jak $w$ zwierciadle (1961), Persona (1966), Hańba (1968) oraz Namiętność (1969). Poza tym Bergman nakręcił tu dwa filmy dokumentalne Dokument $z$ Fårö 69 (1969) i Dokument z Fårö 79 (1979), a także serial telewizyjny Sceny z życia małżeńskiego (1973). Zrealizowano tu również film Wiarołomni (2000) wyreżyserowany przez Liv Ullmann według scenariusza Bergmana.

Reżyser od początku umiejętnie wykorzystywał w filmie pejzaż, ów „emocjonalny krajobraz" nazywany przez Siergieja Eisensteina „nieobojętną przyrodą" (Eisenstein 1975: 298). Zanim Bergman odkrył Fårö, korzystał w swoich filmach z wyspiarskich krajobrazów szkierów sztokholmskich oraz półwyspów Bjäre i Kullen w Skanii. O ile szkiery były elementem słonecznej sielanki w Wakacjach $z$ Moniką (1952) czy Tam, gdzie rosna poziomki (1957), o tyle skańskie półwyspy, bardzo przypominające skaliste Fårö, „zagrały” w mrocznych obrazach Wieczór kuglarzy (1953), Siódma pieczęć (1957) i Godzina wilka (1968). Warto w tym miejscu odno-

\footnotetext{
${ }^{11}$ Podobnego porównania użył Timm w biografii, nazywając Fårö „jego własnym królestwem z demonami i ludźmi” (Timm 2008: 398).

12 O toposie wycofania się artysty i życiu „poza ciężarami cywilizacji” pisał Miłosz w eseju Życie na wyspach, z tym że w jego ujęciu chodzi o konflikt bohemy ze społeczeństwem (Miłosz 1997).

${ }_{13}$ Zob. Shell (2014). Kanadyjski literaturoznawca poświęcił Bergmanowi cały rozdział. Jednak $\mathrm{z}$ racji szeroko zakrojonego tematu jest to przegląd dość pobieżny, niemniej wskazujący na pewne istotne zagadnienia.
} 
tować, że właśnie Godzinę wilka często błędnie ${ }^{14}$ przypisuje się lokalizacji na Fårö, zapewne ze względu na akcję rozgrywającą się na wyspie oraz datę premiery filmu ${ }^{15}$.

W pierwszym filmie zrealizowanym na Fårö zatytułowanym Jak $w$ zwierciadle Bergman w ascetycznej scenerii wyspy podejmuje problem poszukiwania Boga ${ }^{16}$. Na wybrzeżu, na kamiennej plaży stoi letni dom schizofrenicznej Karin i jej rodziny, w którym rozegra się dramat. Nykvist twierdził wręcz, że film zauważono na świecie właśnie ze względu na ów pejzaż i północne światło i że to dzięki nim nagrodzono go w 1961 roku Oscarem (Nykvist 2006: 82).

Kolejne filmy: Persona, Hańba i Namiętność zostały napisane specjalnie dla krajobrazu Fårö. Wyspie w Personie ponownie przypisana zostaje rola leczniczego refugium. Główna bohaterka Elisabet Vogler w odizolowanym domku letniskowym ma dojść do siebie pod opieką pielęgniarki Almy. „Jest on położony nieco na uboczu. Przed nim, od strony północnej, rozciąga się podłużny skrawek plaży. Od zachodu widać stromą skalistą zatokę. Za domkiem, w oddali, wrzosowisko i las" - czytamy w scenariuszu (Bergman 1977: 299). To opis plaży, przy której dwa lata później stanie dom Bergmana.

„Persona to - jak pisze Egil Törnqvist - najtrudniejszy do interpretacji film Bergmana” (Törnqvist 1993: 62). Szczepański z kolei zalicza ten utwór „do najbardziej enigmatycznych i hermetycznych w historii dwudziestowiecznej sztuki"17 (Szczepański 1999: 277). Okrojone do dwóch protagonistek i niemal jednego miejsca akcji dzieło stało się na przestrzeni lat przedmiotem wielu interpretacji przeprowadzanych z najróżniejszych pozycji badawczych.

Jedną z nich jest spojrzenie z perspektywy społeczno-politycznej, zaproponowane przez szwedzkiego badacza Erika Hedlinga. W jego ujęciu twórczość Bergmana stanowi krytykę szwedzkiego społeczeństwa i zsekularyzowanego państwa dobrobytu $^{18}$ (Hedling 2008a: 180). Próbuje to pokazać, przeprowadzając między innymi analizę sekwencji przedstawiającej krajobraz w Personie. Na potrzeby tej analizy dzieli krajobrazy w filmie na utopijne, czyli te podlegające kategorii piękna, „trwale zakodowane metafory szwedzkości”, obecne w szwedzkim kinie do

\footnotetext{
${ }^{14}$ Np. Garzia (red.) 2001: 25, 101-102; Steene 2005: 40; Aubron 2007: 14. Co prawda Steene nie mówi wprost o kręceniu tego filmu na Fårö, jednak można to tak zrozumieć, gdy pisze: „Fårö stanowi symboliczną scenerię kilku obrazów, które można by nazwać filmami wyspiarskimi Bergmana" i wymienia Jak w zwierciadle, Personę, Godzinę wilka, Hańbę, Namiętność oraz Dotyk.

${ }_{15}$ Pracę nad scenariuszem do filmu Bergman rozpoczął jesienią 1964 r. Przerwał ją jednak z powodu choroby, potem zmienił plany i latem 1965 r. nakręcił najpierw Personę, a dopiero rok później Godzinę wilka. Premiera filmu odbyła się jeszcze później, bo w 1968 r. Stąd prawdopodobnie zamieszanie dotyczące lokalizacji zdjęć do filmu.

${ }^{16}$ Jeśli chodzi o omówienie filmu, odsyłam do monografii Szczepańskiego (1999: 237-241).

17 Więcej na ten temat zob. Szczepański 1999: 276-283.

${ }^{18}$ Warto zaznaczyć, że jak sam zauważa, jest w tej postawie odosobniony (Hedling 2008a: 180).
} 
$1960^{19}$ roku, oraz postutopijne, czyli „ponure, jałowe, wstrętne”, „sugerujące, że źle się dzieje w państwie szwedzkim", obecne w filmach po 1960 roku (Ibid.: 183). Przy czym należy w tym miejscu dodać, że wspominając o takim właśnie odludnym i nieprzyjaznym krajobrazie w Wiarołomnych, przyznaje, że jest on jednocześnie „osobliwie piękny” (Ibid.: 186).

Według Hedlinga twórca Persony ukazuje rysę na szwedzkim dobrobycie, zastępując wcześniejsze uświęcone i idylliczne krajobrazy szwedzkie obrazami ponurymi. Badacz przywołuje sekwencję, w której do sfilmowania idących po skalistej plaży kobiet zastosowano jazdę równoległą kamery ${ }^{20}$. Widoczna w niej „przeraźliwie zwichrowana roślinność" jest $\mathrm{w}$ jego rozumieniu metaforycznie powiązana $\mathrm{z}$ „wynaturzonymi umysłami” bohaterek, będącymi z kolei produktem „racjonalistycznego społeczeństwa [...] na skraju załamania”. „Z punktu widzenia szwedzkiej tradycji filmowej krajobraz jest zatem 'załamaniem', tu przedstawionym za pomocą słynnej sekwencji jazdy równoległej, towarzyszącej kłócącym się kobietom, idącym na plaży na Fårö” - konkluduje Hedling (Ibid.: 187).

Podczas prac nad kolejnym filmem kręconym na Fårö Bergman wraz ze swoją ówczesną partnerką Liv Ullmann mieszkali już w nowo wybudowanym domu na wyspie. Hańba (1968) opowiada o parze muzyków - Evie i Janie Rosenbergach, granych przez Liv Ullmann i Maxa von Sydowa - mieszkających samotnie w małym gospodarstwie na wyspie, która nagle przeobraża się w arenę walk wojennych. Żyjący w izolacji na marginesie społeczeństwa apolityczni artyści stają się ofiarami politycznych rozgrywek. Okrucieństwo wojny, przemoc fizyczna i psychiczna służą ukazaniu dylematu jednostki w obliczu zagrożenia.

„W Hańbie wyspa [...] była nie tylko stanem duszy autora, ale stała się również symbolem Szwecji, peryferyjnego państwa europejskiego, które od blisko stu sześćdziesięciu lat nie brało udziału w żadnej wojnie [...]" (Szczepański 1999: 297).

W przeciwieństwie do kameralnej Persony ta realizacja wymagała udziału dużej ekipy i wielu statystów. Zatrudniono żołnierzy z jednostki na Gotlandii i mieszkańców Fårö. Ponieważ w latach 60 . wyspa wyludniała się, realizatorzy mieli do dyspozycji wiele opuszczonych zabudowań, które „zagrały” w filmie. Wraz $\mathrm{z}$ nieprzystępnym i surowym krajobrazem tworzyły one wymarzoną scenerię dla „koszmaru sennego" Bergmana ${ }^{21}$.

Film kręcono w kilkunastu lokalizacjach rozsianych na całej wyspie, w tym na plaży z raukami. W końcowej scenie filmu Eva i Jan, czekając na łódź, którą wy-

\footnotetext{
${ }^{19}$ Co ciekawe, Hedling podaje, że „celebracja szwedzkiego krajobrazu stanowi integralną część ponad jednej trzeciej filmów wyprodukowanych w Szwecji między 1940 a 1959 rokiem”, i że tradycja ta jest silniejsza w szwedzkim kinie niż w innych kinematografiach (Hedling 2008a: 182). ${ }^{20} \mathrm{~W}$ tym celu położono na plaży tory długości 175 metrów. Było to spore wydarzenie, a uroczyste otwarcie świętowała cała ekipa filmowa wraz z mieszkańcami wyspy (Brogren 2014b: 133). ${ }^{21}$ Więcej o filmie zob. Szczepański 1999: 294-298.
} 
dostaną się z wyspy, siedzą wsparci plecami o rauk na plaży Langhammar. Jednak wysokiej na sześć metrów skały nie widać w kadrze, zgodnie ze wspomnianym już założeniem reżysera, że specyficzny rauk skupiłby na sobie całą uwagę widza, odciągając ją od treści filmu (Brogren 2014a: 97).

\section{Czarno-białe Fårö w kolorze. Namiętność (1969)}

„Dla mnie Fårö jest czarno-białe” mówi Lars von Trier w filmie Więcej niż Bergman. Podobne odczucia miał reżyser Ang Lee, który w trakcie swojego pobytu na Fårö dziwił się, że wyspa jest kolorowa: „Nie jest czarno-biała, co za dziwne uczucie!” (Lee i Schamus 2007: 47). „Tu na wyspie - wspominała Ullmann w Przemianach - znalazłam się w dziwnym świecie o dziwnych drzewach i kamieniach. Dopiero stopniowo wyłaniały się z tego barwy" (Ullmann 1988: 78). Przytłumione kolory Fårö po raz pierwszy zagrały w filmie, który z założenia miał być „,czarno-białym filmem w kolorze z pewnymi mocnymi akcentami na bardzo dyskretnej gamie barwnej" (Bergman 1993: 307).

Namiętność, „pierwszy prawdziwy film barwny” Bergmana, pod wieloma względami nawiązuje do Hańby, jest wariacją na jej temat. „W obu filmach jest ten sam krajobraz, ale konkretne zagrożenia z Hańby stały się w Namiętności bardziej subtelne. [...] Sen w Namiętności zaczyna się tam, gdzie kończy się rzeczywistość Hańby" - pisze autor o filmie (Bergman 1993: 307).

Dwie pary niczym więźniowie na wyspie zmagają się z samotnością i bezsensem istnienia w atmosferze absolutnej izolacji: Anna (Liv Ullmann) i Andreas (Max von Sydow), Eva (Bibbi Andersson) i Elis (Erland Josephson). Anna jest wdową, swoje życie buduje na kłamstwie szczęśliwego małżeństwa, Andreas odizolował się na własne życzenie, nie chce już uczestniczyć w życiu, Eva postrzega siebie jako bezwartościowy dodatek do męża, a Elis, jej mąż, cyniczny architekt, uważa, że człowiek skazany jest na samotność. Kilka lat później ten kameralny dramat rozpisany na cztery role $\mathrm{z}$ morzem i rozległymi, bladymi krajobrazami $\mathrm{w}$ tle ulegnie kondensacji i przybierze formę Scen z życia małżeńskiego, kolejnego filmu zrealizowanego na Fårö, ale tym razem tylko we wnętrzach.

\section{8. „Piękny obraz z Fårö”. Sceny z życia małżeńskiego (1973)}

Twórcę Persony od początku fascynowały nowe możliwości, jakie dawała produkcja telewizyjna, zarówno od strony artystycznej, jak i ekonomicznej. A że w latach 70. telewizja stawała się dominującym medium wypierającym kino, reżyser zdecydował się na zrealizowanie kolejnego projektu $\mathrm{w}$ formie serialu 
telewizyjnego ${ }^{22}$. Zdjęcia do Scen z życia małżeńskiego rozpoczęto 24 lipca 1972 roku, i o ile Hańba niemal w stu procentach rozgrywała się w plenerze, o tyle niemal cały serial nakręcono we wnętrzach: początkowe ujęcia w willi w Djursholm w Sztokholmie, a większość w Dämba i Hammars na Fårö (Brogren 2014a: 120).

Sześcioodcinkowy dramat kameralny o rozpadzie małżeństwa Marianne (Liv Ullmann) i Johana (Erland Josephson) nadano w telewizji szwedzkiej na wiosnę 1973 roku. Każdy z odcinków kończył się głosem Bergmana z off-u: „Właśnie obejrzeli państwo xxx odcinek Scen z życia małżeńskiego pod tytułem xxx. Podczas gdy będą państwo patrzeć na ten piękny obraz z Fårö, opowiem państwu, kto nad czym pracował w tym filmie" 23 . Po czym reżyser wymieniał po kolei wszystkich - oprócz siebie - członków ekipy filmowej.

Ów „piękny obraz z Fårö” nie tylko w każdym odcinku był inny, lecz także zaprezentowany został w różny sposób. W pierwszym, drugim i szóstym odcinku zastosowano powolny odjazd kamery, w trzecim i piątym - niemal nieruchomy kadr, a w czwartym - lekki najazd kamery.

Podobnie jak w poprzednich filmach fabularnych Bergman pominął spektakularne elementy pejzażu wyspy, skupiając się na szczegółach. Nie widzimy więc słynnych rauków, ale ujęcie drzew odbitych w wodzie, na którą pada deszcz (odcinek 4. zatytułowany Dolina łez) ${ }^{24}$, pojedynczy kamień, który po odjeździe kamery okazuje się częścią murku typowego dla Fårö (odcinek 2.), czy latarnię morską na kamienistej plaży (odcinek 3.) ${ }^{25}$.

Pojawiający się nagle po zakończeniu filmu obraz jest zaskakujący, ale dzięki zbliżeniom charakterystycznym dla nykvistowskiego operowania obrazem łączy jednocześnie otwartą przestrzeń krajobrazu z zamkniętą przestrzenią wnętrza, w której rozgrywa się dramat Marianne i Johana, dając mu czas na wybrzmienie, a widzom czas do namysłu. Bezruch lub bardzo powolny ruch kamery wzmacniają to wrażenie.

Można by zastanowić się nad znaczeniem tego zestawienia. Czy stworzone w ten sposób opozycje zamknięty-otwarty, pełny-pusty, kultura-natura miały na celu umieszczenie małżeńskiej walki pary protagonistów w szerszym kontekście? Bergman najpierw przeprowadził wiwisekcję małżeństwa godną Domu lalki Ibsena czy Tańca śmierci Strindberga, po czym zaproponował widzom kontemplowanie krajo-

22 Więcej na temat „soap opery à la Bergman” zob. Szczepański 1999: 337-343.

${ }^{23}$ Jeśli chodzi o mówione napisy końcowe, Hedling doszukuje się źródła inspiracji w filmie Orsona Wellesa Wspaniałość Ambersonów z 1942 r. (Hedling 2008b: 82). Podobny zabieg zastosowali jednak później też Jean-Luc Godard w Pogardzie (1963) i François Truffaut w Fahrenheit 451 (1966).

${ }^{24}$ Osobnym zagadnieniem, wychodzącym poza ramy tego artykułu byłoby zbadanie, czy - a jeśli tak, to w jaki sposób - treść poszczególnych odcinków koresponduje z następującymi po nich obrazami.

${ }^{25}$ Wydaje się, że większość zdjęć powstała w bezpośrednim sąsiedztwie stodoły-atelier w Dämba i przedstawia jezioro Dämbaträsk. 
brazu pozbawionego ludzi, przy jednoczesnym stwierdzeniu, że jest to „piękny obraz”. Związał też film z konkretną lokalizacją - z Fårö, czyli ze swoim miejscem na ziemi.

O tym, że reżyser przywiązywał wagę do tego rodzaju zakończenia każdego odcinka, świadczył fakt, że o ile bez żalu zgodził się na znaczne skrócenie serialu na potrzeby kina ${ }^{26}$, o tyle niechętnie przystał na zrezygnowanie $\mathrm{z}$ „napisów” końcowych (Ingmarbergman 2018).

\section{Hollywood na Fårö}

W 1967 roku, czyli w tym samym czasie, w którym osiedlił się na Fårö, Bergman stworzył własną spółkę produkcyjną, którą w hołdzie wynalazkowi braci Lumière nazwał Cinematographem. Firma współprodukowała wszystkie filmy kinowe i telewizyjne reżysera począwszy od Hańby, a także brała udział w produkcjach innych twórców, którymi najczęściej byli przyjaciele Bergmana ${ }^{27}$. W Obrazach tak wspominał ten czas: „Nasza mała firma produkowała filmy innych reżyserów i pieniądze napływały strumieniami. [...] Mogłem robić, co chciałem, i każdy wyrażał gotowość sfinansowania moich starań" (Bergman 1993: 77-79).

Sukces finansowy Cinematograph zawdzięczał jednak głównie Scenom z życia małżeńskiego. W związku z realizacją tego serialu w gazetach mówiono o tym, że „Bergman zbudował na Fårö najnowocześniejsze studio filmowe w Szwecji”, albo że buduje tam miasteczko filmowe, małe Hollywood (Steene 2005: 852). Spółka miała co prawda siedzibę w Sztokholmie, ale to na wyspie zbudowano w Dämba małe atelier. Początkowo na potrzeby „nielicznych scen we wnętrzach w Hańbie, a także po to, by zespół miał gdzie przesiadywać. Była to prowizoryczna budowla przeznaczona do rozbiórki po zakończeniu zdjęć do filmu. Ingmar postanowił jednak ją zachować, myśląc skrycie o dalszych produkcjach w tamtej okolicy, niedaleko jego domu (Nykvist 2006: 90).

Zakrojonych na szeroką skalę planów rozbudowy studia nie zrealizowano, a działalność firmy uległa zahamowaniu po wyjeździe reżysera ze Szwecji w 1976 roku.

\section{Dokument z Fårö 69 (1969)}

Życie Bergmana na „uprzywilejowanym marginesie” społeczeństwa nie wykluczało angażowania się w sprawy lokalnej społeczności. Co prawda, jak twierdził, zamieszkał na wyspie z zamiarem wycofania się ze świata, czytania książek, których

${ }^{26}$ Sześć odcinków, które w sumie trwały 281 minut, skrócono do 169 minut.

${ }_{27}$ Firma wyprodukowała filmy Gunnel Lindblom, Kjella Grede, Svena Nykvista i Erlanda Josephsona. 
jeszcze nie przeczytał. Chciał też „medytować, oczyścić duszę”. Po jakimś miesiącu był już jednak „beznadziejnie zaangażowany w problemy mieszkańców wyspy, co dało w rezultacie Dokument $z$ Fårö 69”28 (Bergman 1991: 198).

Autorem zdjęć został Sven Nykvist, który miał już doświadczenie w filmowaniu dokumentów w Afryce. Dobrze wspominał realizację tego, jak go nazwał, „skromnego filmu” ze względu na jego kameralny charakter. „Choć raz mogłem pracować zupełnie bez ograniczeń - pisał - bez wielkiego zespołu i presji terminów, w zasadzie w samotności, $\mathrm{z}$ towarzyszeniem tylko kamery i Ingmara (Nykvist 2006: 91-92). W pracy nad filmem Nykvistowi asystował Arne Carlsson, mieszkaniec wyspy, który pracował dla Bergmana od 1967 roku. Początkowo jako kierowca i „złota rączka”, potem jako asystent operatora, a wreszcie jako fotograf i samodzielny operator filmowy (por. Blomberg 2014a: 179-187).

Bergmana interesowała nie wyspa jako taka, ale losy zamieszkujących ją ludzi. Zależało mu, jak wynika z relacji Carlssona, na ukazaniu jak największej różnorodności, dlatego poszukiwał rozmówców w różnym wieku i różnych zawodów (Blomberg 2014a: 181). I tak o problemach wyspy dowiadujemy się od grupy młodzieży dojeżdżającej do szkoły na Gotlandię, od emerytów, hodowcy owiec, rolników, rybaków, urzędniczki pocztowej, bibliotekarki i nauczycielki.

Reżyser sam przeprowadził wszystkie wywiady, pełnił też w filmie funkcję narratora. Wyjątkowym wyczuciem i znajomością natury ludzkiej zachwycił recenzenta dziennika Dagens Nyheter Mauritza Edströma, który okrzyknął go doskonałym reporterem, a film zaliczył do najlepszych w dorobku Bergmana, podkreślając jego prostotę i realizm (Edström 1970, cyt. za: Deutsche Kinemathek 2011: 211). Sam Bergman odnosił się do tych pochwał sceptycznie, nie lubił zresztą dokumentów poza filmami przyrodniczymi Davida Attenborough (Timm 2008: 526).

$\mathrm{Na}$ szczególną uwagę zasługuje formalna strona filmu, w którym Bergman przeplótł wywiady nagrane na taśmie czarno-białej z kolorowymi obrazami fårörskich pejzaży. Zastosował także śródnapisy i umieścił w nich dedykację: „mieszkańcom Fårö”. Już samo zrobienie filmu o mieszkańcach wyspy można odebrać jako wyznanie miłości ${ }^{29}$. Tak odczytał też film Carlsson, mówiąc, że w ten sposób Bergman odwdzięczył się za wszystko, co zamieszkujący wyspę ludzie zrobili dla niego (Blomberg 2014a: 181).

Gdy Edström w dzień po emisji filmu w telewizji szwedzkiej uznał Bergmana za doskonałego reportera, nie mógł jeszcze wiedzieć, że Dokument $z$ Fårö 69 zupełnie nieoczekiwanie stanie się reportażem interwencyjnym i wpłynie bardzo konkretnie na życie dzieci ze szkoły podstawowej na wyspie. Otóż poruszając w tym dokumencie wiele kwestii społecznych i politycznych związanych z biedą, wyklu-

${ }^{28}$ Film powstał w dwóch wersjach: dłuższej, 88-minutowej, która miała premierę 1 stycznia 1970 r., oraz krótszej, 57-minutowej, wyświetlonej 27 marca 1970 r.

${ }^{29}$ Bergman nie nadużywał tego rodzaju wynurzeń. O pierwszej osobistej dedykacji reżysera zob. Szczepański 1999: 237. 
czeniem i życiem na marginesie społeczeństwa, Bergman zakończył film płomienną przemową, w której życzył nauczycielce z Fårö, aby jej uczniowie uzyskali dofinansowanie na podróż po kraju. Apel został wysłuchany przez jednego z widzów i już kilka miesięcy później mali Fåröjczycy siedzieli na pokładzie samolotu do Kalmaru w drodze na szwedzki stały ląd (Blomberg 2014b: 215-216).

\section{Emigracja i Fårö}

Nie sposób omówić drugiego Dokumentu $z$ Fårö, nie wspominając o dramatycznej emigracji Bergmana w 1976 roku. W styczniu oskarżony o oszustwo podatkowe reżyser był przesłuchiwany przez policję, $\mathrm{w}$ wyniku czego doznał załamania nerwowego. W połowie marca przeniósł się ze Sztokholmu, gdzie pracował w teatrze, na Fårö. Tam podjął decyzję o opuszczeniu Szwecji na stałe. W liście pożegnalnym do społeczeństwa szwedzkiego zdruzgotany Bergman pisał: „Fårö było moim bezpieczeństwem, spoczywałem jak w łonie matki, bez jednej myśli o tym, że kiedyś jeszcze w życiu stanę przed koniecznością wyjazdu" (Bergman 1991: 98).

Szybko okazało się jednak, że Fårö nie jest dla niego tożsame ze Szwecją. „Mógł opuścić Szwecję, ale nie Fårö” (Timm 2008: 487). Dlatego mylące jest dość powszechne wyobrażenie, że Bergman w latach 1976-1981 na dobre opuścił kraj ${ }^{30}$. Owszem, nie pracował tam w teatrze, nie kręcił filmów fabularnych, ale sporo czasu spędzał na Fårö.

Bez swojego azylu na wyspie nie mógł funkcjonować. Już parę dni po głośnym opuszczeniu Szwecji reżyser wynajął samolot i poleciał na Fårö na jeden dzień. Potem, gdy po dwóch dniach w Los Angeles, gdzie miał spędzić lato, Barbra Streisand zadzwoniła i zaprosiła go z Ingrid na małe party nad brzegiem basenu, Ingmar jej podziękował i oświadczył żonie: „Natychmiast jedziemy do domu na Fårö i zostaniemy tam przez lato. Wyśmiewanie jakoś zniesiemy”. Kilka godzin później byli już w drodze. O pierwszym wieczorze po powrocie do Szwecji Bergman zanotował: „Wszystko było najpiękniejsze i pachniało najmocniej. I to światło” (Bergman 1991: 103). Innym razem pisał: „12 kwietnia 1979 przyjechaliśmy na Fårö. To jest jak powrót do domu. 'Wszystko inne jest snem i nierzeczywistością"' (Bergman 1993: 370).

\section{Dokument z Fårö 79 (1979)}

W kontekście tych zawirowań nie dziwi fakt, że o ile prace nad pierwszym dokumentem trwały dwa miesiące, o tyle realizacja drugiego rozciągnęła się na ponad dwa

${ }^{30}$ Por. Garzia (red.) 2001: 22, gdzie znajdziemy informację, że Bergman zmuszony był przebywać z dala od swojej wyspy w latach 1976-1981. 
lata. O ile pierwszy był zbliżeniem się do mieszkańców wyspy, o tyle w drugim autor jest już tam zadomowiony. To film o sąsiadach, a nie o obcych (Timm 2008: 524).

Zaangażowanie emocjonalne reżysera, większość czasu spędzającego za granicą i tęskniącego za krajem, sprawiło, że film jest bardziej hymnem pochwalnym ${ }^{31}$ w Mickiewiczowskim duchu „Dziś piękność twą w całej ozdobie / Widzę i opisuję, bo tęsknię po tobie" ${ }^{\prime 2}$ niż głosem w społecznej debacie, tak jak to było w przypadku Dokumentu $z$ Fårö 69. Jego wymowa jest bardziej intymna, obrazy bardziej fragmentaryczne, dobór rozmówców zdaje się bardziej przypadkowy, przez co brak ogólnego obrazu społeczności wyspy. Pesymistyczny ton pierwszego dokumentu zastąpił optymizm: warunki życia na Fårö poprawiły się, a młodzież, która dziesięć lat wcześniej deklarowała chęć opuszczenia wyspy, została.

Dokument $z$ Fårö 79 różni się od swojego poprzednika nie tylko treścią, ale też formą. Zwraca uwagę zastosowanie planów ogólnych i amerykańskich, które jak to ujął Edström - „przeczą telewizyjnym przyzwyczajeniom” (Edström 1979, cyt. za: Deutsche Kinemathek 2011: 213). Można się domyślać, że zmianę formy spowodowała zmiana operatora. Carlsson, który podczas prac nad pierwszym dokumentem dopiero uczył się rzemiosła u mistrza Nykvista, teraz samodzielnie pokierował kamerą. Steene twierdzi nawet, że dostał od Bergmana wolną rękę i że film w dużym stopniu jest jego dziełem. Świadczyć miałby o tym montaż nadający filmowi inny, wolniejszy rytm ${ }^{33}$ (Steene 2005: 431-432).

Drugi dokument tak samo jak pierwszy miał premierę w telewizji szwedzkiej w czasie największej oglądalności w wigilię Bożego Narodzenia 1979 roku. Również $\mathrm{i}$ ten dokument spotkał się z dużym społecznym odzewem, tym razem o nieco humorystycznej wymowie. Okazało się bowiem, że widok jednego z bohaterów filmu, Valtera Bromana, używającego do smażenia ryb noża-łopatki do sera tak poruszył serca szwedzkich gospodyń, że po emisji filmu otrzymał on bez mała dwieście listów i paczek zawierających łopatki do smażenia (Brogren 2014c: 199).

Właśnie jego osobie reżyser poświęcił szczególną uwagę. Broman, rolnik z Dämba i sąsiad Bergmana, samotnie prowadził gospodarstwo odziedziczone po rodzicach. Reżyser przez rok przyglądał się jego życiu i pracy na roli, której porządek nadawały pory roku. Opowiadał, że Broman żył i pracował w totalnym, dobrowolnie wybranym odosobnieniu. Nietrudno dostrzec w tej fascynacji projekcję własnej postawy życiowej. Mówiąc o „dobrowolnie wybranym odosobnieniu”, Bergman miał na myśli siebie, bo przecież trudno ocenić, na ile samotność Bromana była jego wyborem.

\footnotetext{
${ }^{31}$ Zwraca na to uwagę też Steene (2005: 431).

32 Podobnie było zresztą ze Strindbergiem - kolejna analogia, łącząca obu twórców - który swoje utwory opiewające Szwecję też tworzył na emigracji, notabene w Bawarii.

${ }_{33}$ Pierwszy dokument montowała Siv Lundgren, a drugi Sylvia Ingemarsson, to także mogło wpłynąć na różnicę.
} 
Litewski filozof Leonidas Donskis, nazywając Fårö projekcją duszy Bergmana, widzi w tej wyspie „miejsce cichej kontemplacji i konfrontacji z własnym ja, miejsce, w którym natychmiast opadają społeczne maski” (Donskis 2011: 191). Ullmann, pisząc o ludziach z Fårö - „wyspiarzach”, również podkreśla, że nie dbają oni o zachowanie maski i fasady, mają odwagę pokazania, kim są. Żyją blisko ziemi, blisko morza, blisko tego, co jest ich naturalnym przeznaczeniem. Charakteryzuje ich prostota, mają zaufanie do swojego miejsca na ziemi, mają korzenie, „którymi przez całe życie tkwili w tym samym kawałku ziemi” (Ullmann 1988: 71). To tłumaczy symbiozę, w jakiej od początku funkcjonowali Bergman i mieszkańcy wyspy.

Reżyser w filmie zapowiedział jego kontynuację w roku 1989, jednak trzecia część dokumentu nigdy nie powstała, ponieważ - jak relacjonował Carlsson - mieli wtedy dużo pracy, a Bergman stracił zainteresowanie i zapał do projektu (Blomberg 2014a: 181). W latach 1985-1986 obaj stworzyli jednak film o innej wyspie, mniejszej od Fårö i położonej na północ od niej - Gotska Sandön. Dokument pod tym samym tytułem wyreżyserował Carlsson, a Bergman był tylko producentem.

\section{Staruszek z Fårö}

Włoski filmoznawca Sergio Arecco postrzega Fårö jako „miejsce samotności i milczenia, nagie i fundamentalne, miejsce introspekcji i metafizycznych podróży w głąb, krajobraz wybrany, który najlepiej odsłania nagi ból własnego ja" (Garzia 2001: 19). Istnieje jednak drugie oblicze wyspy, niewidoczne w filmach, ale obecne i istotne dla prywatnego życia reżysera. To tu po raz pierwszy spotkało się dziewięcioro dzieci Bergmana z okazji jego sześćdziesiątych urodzin. Domy na Fårö stały się centrum życia rodzinnego, a rozległa posiadłość umożliwiała jednoczesny pobyt wielu gości. Dzieci, a potem wnuki Bergmana spędzały tam wakacje, a reżyser zapraszał wszystkich do uczestniczenia w słynnych codziennych pokazach filmów o godz. 15.00 w swoim kinie w Dämba, „zrealizowanym marzeniu z dzieciństwa” (Bergman 1991: 223). Wieczorem Bergman oglądał filmy wideo lub telewizję „człowiek mieszkając na Fårö staje się telemaniakiem” - mawiał (Bergman 1972, cyt. za: Hedling 2008b: 72). „Z pedanterią ustaliłem tryb życia” - pisał. „Wstawałem wcześnie, spacerowałem, pracowałem, czytałem. O piątej przychodziła sąsiadka, przygotowywała obiad, zmywała naczynia i odchodziła. O siódmej znów byłem sam" (Bergman 1991: 199).

Mówił o sobie fårögubbe - „staruszek z Fårö”. Od 2003 roku, kiedy przeprowadził się na wyspę na stałe, został nim na dobre. Mimo naturalnego dystansu dzielącego go od mieszkańców starał się być jednym z nich. Już w 1967 roku zameldował się na wyspie i płacił tam podatki. Sfinansował remont wiejskiego domu kultury i zatrudniał wielu mieszkańców. W zamian otrzymywał ochronę swojej 
prywatności. Nikt z miejscowych nie zdradził nigdy poszukującym turystom jego miejsca zamieszkania, co stało się już legendą. Do ostatniej chwili udało się nawet utrzymać w tajemnicy termin pogrzebu, cała wyspa solidarnie milczała.

\section{Na zawsze na Fårö}

Rita Russek, odtwórczyni roli Kathariny Krafft w filmie $Z$ życia marionetek (1980), znalazła się w wąskim gronie przyjaciół zaproszonych przez Bergmana na pogrzeb, perfekcyjnie wyreżyserowany, jak na mistrza przystało. Wszystko ustalone zostało wcześniej, co do najmniejszych szczegółów, łącznie z trumną wykonaną z lokalnego drewna przez miejscowego stolarza na wzór tej Jana Pawła II. „Wydawało się - wspomina Russek - że nawet promień słońca padający na samotną różę na trumnie jest elementem jego inscenizacji” (Russek 2011: 89; Pergament 2007).

Po śmierci Bergmana pojawiło się pytanie, co dalej z jego dziedzictwem na Fårö. Zgodnie z ostatnią wolą reżysera wszystkie jego nieruchomości wraz ze znajdującymi się w nich przedmiotami miały zostać sprzedane, a pieniądze podzielone równo między jego dzieci. Wydawałoby się, że najlepszym rozwiązaniem będzie zaangażowanie się państwa w zakup i zabezpieczenie spuścizny po największym szwedzkim twórcy. Państwo jednak finansowania odmówiło i cały majątek reżysera wystawiono na sprzedaż. Po zakończonej aukcji okazało się, że nieruchomości oraz większość dobytku zakupił norweski multimilioner Hans Gude Gudesen i przekazał do dyspozycji Fundacji Bergmangårdarna powołanej przez najmłodszą córkę Bergmana, Linn Ullmann (Lindström 2009). Dzięki jej zaangażowaniu udało się zachować jego uniwersum na wyspie. Teraz domy reżysera przeobrażono w miejsca pracy twórczej.

Od 2013 roku działa też na wyspie Centrum Bergmana z małym muzeum i kinem. Powołany do życia w 2004 roku festiwal Tydzień Bergmanowski ma tam swoją siedzibę. Raz w roku pod koniec czerwca miłośnicy twórczości wielkiego Szweda zaludniają wyspę i biorą między innymi udział w Bergmanowskim Safari śladami jego filmów na Fårö.

Mimo że Bergman opuścił Fårö, pozostał tam jednak na zawsze. A jego miłość do wyspy umieściła ten skrawek ziemi na mapie świata. Jakiego znaczenia nabrało to miejsce, doskonale uzmysławia wypowiedź meksykańskiego reżysera Alejandro G. Iñárritu, który w filmie Więcej niż Bergman ${ }^{34}$ powiedział: „Gdyby film był religią, ta wyspa byłaby Mekką lub Watykanem”. W naszej świadomości Fårö pozostanie wyspą Bergmana.

${ }^{34}$ Film w reżyserii Jane Magnusson i Hynka Pallasa powstał w 2013 r. na bazie sześcioodcinkowego serialu telewizyjnego Bergmans video (2012). Punktem wyjścia dla powstania filmu była pokaźna kolekcja kaset wideo w domu reżysera na Fårö. Twórcy filmu zaprosili tam innych reżyserów, aby porozmawiać o wpływie Bergmana na ich twórczość. 
Bibliografia

Aubron, H. (2007). Voyage à Fårö. Les possibilités d’une île. Cahiers du cinéma Hors série Bergman/Antonioni 14-15.

Bergman, I. (1972). Arbetsboken nr 27 (april). Niepublikowane notatki.

Bergman, I. (1977). Scenariusze. Tłum. A. Asłanowicz et al. Warszawa: Wydawnictwa Artystyczne i Filmowe.

Bergman, I. (1991). Laterna magica. Tłum. Z. Łanowski. Warszawa: Czytelnik.

Bergman, I. (1993). Obrazy. Tłum. T. Szczepański. Warszawa: Wydawnictwa Artystyczne i Filmowe.

Bergström, L. (1991). Den gamle och havet. En försonad Ingmar Bergman. Månadsjournalen 11: 33-45.

Bjørnstad, K. (2007). Liv Ullmann. Linie życia. Tłum. M. Skoczko. Gdańsk: Słowo/obraz terytoria. Blomberg, K. (2014a). Fårösorken som blev Ingmar Bergmans fotograf. W: Fårö och Ingmar Bergman. Ett möte. Fårö: Fårö Hembygdsförenings Förlag, s. 179-187.

Blomberg, K. (2014b). Fåröbarnens drömresa. W: Fårö och Ingmar Bergman. Ett möte. Fårö: Fårö Hembygdsförenings Förlag, s. 215-217.

Brogren, G. (2014a). Inspelningsplatser på Fårö. W: Fårö och Ingmar Bergman. Ett möte. Fårö: Fårö Hembygdsförenings Förlag, s. 57-120.

Brogren, G. (2014b). Invigning av kamerarälsen vid Hammars. W: Fårö och Ingmar Bergman. Ett möte. Fårö: Fårö Hembygdsförenings Förlag, s. 133-143.

Brogren, G. (2014c). Valter vid Dämba - filmstjärna hos Bergman. W: Fårö och Ingmar Bergman. Ett möte. Fårö: Fårö Hembygdsförenings Förlag, s. 197-199.

Copper, P. (2004). Silurian (late Llandovery-Ludlow) Atrypid Brachiopods from Gotland, Sweden, and the Welsh Borderlands, Great Britain. Ottawa: NRC Research Press.

Deutsche Kinemathek. (2011). Ingmar Bergman: Essays, Daten, Dokumente. Berlin: Bertz + Fischer Verlag.

Donskis, L. (2011). Modernity in Crisis. A Dialogue on the Culture of Belonging. New York: Palgrave Macmillan.

Edlund, E. (2014). Arkitekten och regissören. W: Fårö och Ingmar Bergman. Ett möte. Fårö: Fårö Hembygdsförenings Förlag, s. 151-162.

Edström, M. (1970). Bergmans film om Fårö. Dagens Nyheter, 2 stycznia 1970.

Edström, M. (1979). Fårödokument 1979. Dagens Nyheter, 26 grudnia 1979.

Eisenstein, S. (1975). Nieobojętna przyroda. Tłum. M. Kumorek. Warszawa: Wydawnictwa Artystyczne i Filmowe.

Erlström, M. (2009). Beskrivning till regional berggrundskarta över Gotlands län. Uppsala: Sveriges geologiska undersökning (SGU).

Fårö och Ingmar Bergman. Ett möte. (2014). Fårö: Fårö Hembygdsförenings Förlag.

Gado, F. (1986). The Passion of Ingmar Bergman. Durham: Duke University Press.

Garzia, A. (red.). (2001). Fårö - La Cinecittà di Ingmar Bergman. Un'isola svedese raccontata con foto, storie, interviste e film. Fårö, Ingmar Bergmans „Cinecittä”. Foton, intervjuer, historier och filmer om en svensk ö. Roma: Sandro Teti Editore.

Hedling, E. (2008a). The Welfare State Depicted: Post-Utopian Landscapes in Ingmar Bergman's Films. W: M. Koskinen (red.). Ingmar Bergman Revisited: Performance, Cinema and the Arts. London-New York: Wallflower Press, s. 180-193.

Hedling, E. (2008b). Konsten att inte sopa problemen under mattan: Ingmar Bergmans „Scener ur ett äktenskap". W: M. Cronqvist, L. Sturfelt i M. Wiklund (red.). 1973: En träff med tidsandan. Lund: Nordic Academic Press, s. 71-84. 
Ingmarbergman. (2018). Scener ur ett äktenskap, http://www.ingmarbergman.se/verk/scenerur-ett-aktenskap (dostęp: 23.03.2018).

Lahr, J. (1999). The Demon-Lover. The New Yorker, 3 maja 1999. https://www.newyorker.com/ magazine/1999/05/31/the-demon-lover (dostęp: 18.01.2018).

Lee, A. i J. Schamus. (2007). Mitt bästa Smultronställe. Anteckningar från Bergmanveckan 2006/ The Ingmar Bergman Notebook, Filmkonst 105: 46-47.

Lindström, L. (2009). Tacka Norge för att Bergmans Fårö återskapas. Expressen, 22 grudnia 2009. https://www.expressen.se/nyheter/inloggad/tacka-norge-for-att-bergmans-faro-aterskapas/ (dostęp: 19.01.2018).

Mankell, H. (2011). Ein einsamer Mann in einem 54 Meter langen Haus. W: N. Warnecke i K. Jaspers (red.). Ingmar Bergman: Von Lüge und Wahrheit. Berlin: Bertz + Fischer Verlag, s. 97-99.

Miłosz, C. (1997). Życie na wyspach. W: C. Miłosz. Życie na wyspach. Kraków: Znak, s. 82-93. Nykvist, S. (2006). Kult światła. O filmach i ludziach. Rozmowy z Bengtem Forslundem. Tłum. J. Balbierz. Izabelin: Świat Literacki.

Pergament, D. (2007). The Enchanted Island That Bergman Called Home. New York Times, 7 października 2007. https://www.nytimes.com/2007/10/07/travel/07cultured.html (dostęp: 20.03.2018).

Rasmussen, S.E. (2015). Odczuwanie architektury. Tłum. B. Gadomska. Kraków: Karakter.

Rousseau, J.J. (1955). Emil, czyli o wychowaniu. Tłum. W. Husarski. Wrocław: Zakład Narodowy im. Ossolińskich.

Russek, R. (2011). Wirklich raffiniert. W: N. Warnecke i K. Jaspers (red.). Ingmar Bergman: Von Lüge und Wahrheit. Berlin: Bertz + Fischer Verlag, s. 87-89.

Sharr, A. (2006). Heidegger's Hut. Cambridge: MIT Press.

Shell, M. (2014). Islandology: Geography. Rhetoric, Politics. Stanford: Stanford University Press.

Steene, B. (2005). Ingmar Bergman: A Reference Guide. Amsterdam: Amsterdam University Press.

Strindberg, A. (1895). Mieszkańcy Hemsoe. Tłum. F. Popławska. Warszawa: T. Paprocki i spółka. Strindberg, A. (1914). Hemsöborna. Stockholm: Albert Bonniers Förlag.

Szczepański, T. (1999). Zwierciadło Bergmana. Gdańsk: Słowo/obraz terytoria.

Timm, M. (2008). Lusten och dämonerna. Boken om Bergman. Stockholm: Norstedts.

Törnqvist, E. (1993). Filmdiktaren Ingmar Bergman. Malmö: Bokförlaget Arena.

Ullmann, L. (1988). Przemiany. Tłum. A. Kreczmar. Warszawa: Iskry.

Warnecke, N. i K. Jaspers (red.). (2011). Ingmar Bergman: Von Lüge und Wahrheit. Berlin: Bertz + Fischer Verlag.

Waśkiewicz, A. (2007). Emil, czyli życie obok społeczeństwa. Etyka 40: 62-76.

Weston, R. (2011). 100 idei, które zmieniły architekturę. Tłum. E. Tomczyk. Raszyn: TMC.

Filmografia

Bergman i wyspa Fårö (Bergman and Faro Island). (2003). [film dokumentalny]. Reżyseria: M. Nyreröd. Szwecja.

Dokument z Fårö 69 (Fårödokument 1969). (1969). [film dokumentalny]. Reżyseria: I. Bergman. Szwecja.

Dokument z Fårö 79 (Fårö-dokument 1979). (1979). [film dokumentalny]. Reżyseria: I. Bergman. Szwecja. 
Fahrenheit 451. (Fahrenheit 451). (1966). [film fabularny]. Reżyseria: F. Truffaut, J.-L. Richard. Wielka Brytania.

Godzina wilka (Vargtimmen). (1968). [film fabularny]. Reżyseria: I. Bergman. Szwecja.

Hańba (Skammen). (1968). [film fabularny]. Reżyseria: I. Bergman. Szwecja.

Jak w zwierciadle (Såsom i en spegel). (1961). [film fabularny]. Reżyseria: I. Bergman. Szwecja. Namiętność (En Passion). (1969). [film fabularny]. Reżyseria: I. Bergman. Szwecja.

Persona (Persona). (1966). [film fabularny]. Reżyseria: I. Bergman. Szwecja.

Pogarda (Le mépris). (1963). [film fabularny]. Reżyseria: J.-L. Godard. Francja, Włochy.

Sceny z życia małżeńskiego (Scener ur ett äktenskap). (1973). [film fabularny]. Reżyseria: I. Bergman. Szwecja.

Siódma pieczęć (Det Sjunde inseglet). (1957). [film fabularny]. Reżyseria: I. Bergman. Szwecja.

Tam, gdzie rosna poziomki (Smultronstället). (1957). [film fabularny]. Reżyseria: I. Bergman. Szwecja.

Wakacje z Monika (Sommaren med Monika). (1952). [film fabularny]. Reżyseria: I. Bergman. Szwecja.

Wiarołomni (Trolösa). (2000). [film fabularny]. Reżyseria: L. Ullmann. Finlandia, Niemcy, Norwegia, Szwecja, Włochy.

Wieczór kuglarzy (Gycklarnas afton). (1953). [film fabularny]. Reżyseria: I. Bergman. Szwecja.

Więcej niż Bergman (Trespassing Bergman). (2013). [film dokumentalny]. Reżyseria: J. Magnusson, H. Pallas. Szwecja.

Wspaniałość Ambersonów (The Magnificent Ambersons). (1942). [film fabularny]. Reżyseria: R. Wise, F. Fleck, O. Welles. USA.

$Z$ życia marionetek (Aus dem Leben der Marionetten). (1980). [film fabularny]. Reżyseria: I. Bergman. Szwecja. 